\title{
Table-Top Lithium Disilicate Ceramic Restoration Thickness Effect on the Stress Distribution in Upper Premolars: 3D Finite Element Analysis
} Efecto del Espesor de la Restauración de Cerámica de Disilicato de Litio de Sobremesa en
la Distribución de Tensiones en los Premolares Superiores: Análisis de Elementos Finitos 3D

Alexandre Luiz Souto Borges ${ }^{1}$; Roberta dos Santos Rangel Silva'; Jefferson David Melo de Matos ${ }^{1}$; Amanda Maria de Oliveira Dal Piva'; Oswaldo Daniel Andreatta Filho'; Guilherme da Rocha Scalzer Lopes ${ }^{1} \&$ João Paulo Mendes Tribst ${ }^{2}$

BORGES, A. L. S.; SILVA, R. S. R.; DE MATOS, J. D. M.; DAL PIVA, A M. O.; FILHO, O. D. A.; LOPES, G. R. S. \& TRIBST, J. P. M. Table-top lithium disilicate ceramic restoration thickness effect on the stress distribution in upper premolars: 3D finite element analysis. Int. J. Odontostomat., 15(4):942-947, 2021.

ABSTRACT: To evaluate the stresses generated in upper premolars rehabilitated with ceramic fragments (table-top) of lithium disilicate on the occlusal surface. An upper premolar was modeled following its anatomical references using computer aided design software (Rhinoceros version 5.0 SR8, USA). The dental tissues were individually designed containing enamel, dentin and periodontal ligament. The main anatomical points were used as parameters for model creation. Ceramic fragments were modeled varying their maximum thicknesses as: $0.5 \mathrm{~mm}, 1.0 \mathrm{~mm}$ and $1.5 \mathrm{~mm}$. Solid geometries were exported to the analysis software (ANSYS 17.2, USA) in STEP format. The materials were considered isotropic, homogeneous and linear, and the values of the elastic modulus of the materials and structures were used to perform a static structural mechanical analysis. The set was submitted to $200 \mathrm{~N}$ load. The system fixation was defined on the basis of the threedimensional model, and the results were obtained in MPa according to the failure criteria of the analyzed materials (tensile stress). Occlusal restoration was not detrimental to mechanical behavior. Stress distribution in the internal region of the restoration was similar between the groups. Thicker fragments presented a lower concentration of tensile stress, therefore suggesting better prognosis in attenuating tensile stresses in the tooth region. More conservative occlusal ceramic fragments presented worse prognosis. However, all evaluated thickness for table-tops support the occlusal rehabilitation of upper premolars when submitted to $200 \mathrm{~N}$ loading.

KEY WORDS: ceramics; finite element analysis; fixed prosthesis.

\section{INTRODUCTION}

Considering the stressful routine faced by many patients, bruxism or briquism is constantly present in dental offices. Bruxism can be defined as a parafunctional habit or non-functional contact that manifests eccentrically (teeth grinding) or centrically (teeth tightening) (Wigdorowicz-Makowerowa et al., 1979). This habit has a multifactorial nature such as of emotional or stress origin. The treatment of bruxism is still debatable. However, among the most accomplished methods are the preparation of an occlusal splint, pharmacological therapy and psychological support therapy (Attanasio, 1997). As a sign of this parafunctional habit, there is the presence of wear on the incisal surface of anterior teeth and occlusal surface of posterior teeth (Calderon et al., 2006), which reduces the vertical dimension of occlusion (VDO). The VDO consists of the jaw's vertical position in relation to the maxilla, measured between two points when the upper and lower teeth are in intercuspid contact in the position of maximum closure (Dawson, 1985). Its decrease does not lead to great discomfort, but it influences the opening and

\footnotetext{
${ }^{1}$ Department of Dental Materials and Prosthodontics, São Paulo State University (Unesp), Institute of Science and Technology, São José dos Campos - SP, Brazil.

${ }^{2}$ Department of Dentistry, University of Taubaté (UNITAU), São Taubaté - SP, Brazil - SP, Brazil.
}

Received: 2021-04-23 Accepted: 2021-08-28 
closing arch of the jaw, which may alter the direct relationship between the teeth that accompany the anterior guidewire (Henriques, 2003). With the need to restore VDO, it is necessary to promote adequate occlusal conditions to achieve orthopedic stability, ensuring an ideal position between muscle and skeleton (Okeson, 2000).

The VDO can be restored from making direct or indirect restorations. Direct restorations are indicated in cases where the height and width of the dental remnant are sufficient to accommodate the direct restoration, avoiding a decrease in its mechanical properties such as adhesion and resistance. Indirect restorations are indicated for cases where the destruction of the tooth structure exceeds acceptable limits for preparing a suitable and durable direct restoration (Magne \& Knezevic, 2009).

Dental ceramics are among the main materials of choice for restoring tooth structure due to its properties of compressive strength, color stability, radiopacity and thermal conductivity being similar to teeth biomimetics and marginal integrity. The search for aesthetics has reflected in an increase of ceramic restorations in anterior and posterior teeth (Kelly \& Benetti, 2011; Matos et al., 2020; Dal Piva et al., 2021). Among the available dental ceramics is glass ceramic reinforced with lithium disilicate crystals (approximately 60-70\%), guaranteeing a very translucent structure to this system while conferring a low refractive index that efficiently reflects light and still allows adequate mechanical resistance (Culp \& McLaren, 2010; Matos et al.; Tribst et al., 2021). In addition to offering a variety of colors and high flexural strength (360 to $400 \mathrm{MPa}$ ), this material is suitable for making restorations with minimum thicknesses which avoids excessive wear for the convenience of prosthetic preparations in the dental structure (Tribst et al., 2019, 2021). These characteristics confer versatility to the material enabling rehabilitation with single crowns in the posterior and anterior region through adhesive cementation.

Furthermore, lithium disilicate allows to manufacturing of restorations using CAD/CAM (Computer aided design/Computer aided manufacture), enabling patients to be rehabilitated immediately with high dimensional accuracy. This material conciliates strength and aesthetics, presenting optical properties similar to those of natural teeth (Kwon et al., 2018). Thus, with technological advances restorative dentistry seeks to preserve the dental structure, thereby avoiding accentuated wear from accumulating and seeking biological and mechanical balance between dental tissues and restorative material (D’Arcangelo et al., 2018).

Table-top or occlusal ceramic fragments are restorations which are usually made in thicknesses between 1.5 and $2 \mathrm{~mm}$. These restorations allow conservative dental preparations or just rounding of the tooth structure. In this way, they preserve pulp vitality avoiding the need for endodontic treatments (Magne et al., 2010). Although there are already reports of cases in the literature that have made restorations for this purpose, there are still no studies that demonstrate how stress dissipates in this restorative modality for premolars.

The study of stress and strain in the dental element simulates the behavior of natural tooth structures and adjacent structures. In this way it allows to predict possible complications that can lead to treatment failure; this means enabling interventions and modifications to be made. For this, many studies use the finite element method (FEA) (Costa et al., 2017). Finite element analysis is used to model structures and analyze their mechanical properties. In order to perform a static structural mechanical analysis, the Poisson ratio and the Elastic modulus of structures and materials are required. This method has advantages over in vitro studies, because it allows repetitions of the experiments and alterations in the designs according to the study hypothesis. It is a method that allows for verifying the force, stress and strains in the structures of any geometric form, in addition to being greatly efficient for research in areas of exact and biological sciences (Campaner et al., 2021). In dentistry, this method allows modeling of prosthetic structures, dental tissues, cortical and medullary bones, and dental materials. (Miyashiro et al., 2011; Tribst et al., 2017a).

Finite element analysis is constituted by the division of a continuous medium in small elements, maintaining the properties of the original geometric. These elements are described by differential equations and solved by mathematical models in order to obtain the desired results (Tribst et al., 2017a; Dal Piva et al., 2018). Therefore, by using this method this study analyzed the influence of table-top restoration thickness on the stress distribution in upper premolars. The null hypothesis was that there would be no significant difference between the restored groups. 
BORGES, A. L. S.; SILVA, R. S. R.; DE MATOS, J. D. M.; DAL PIVA, A M. O.; FILHO, O. D. A.; LOPES, G. R. S. \& TRIBST, J. P. M. Table-top lithium disilicate ceramic restoration thickness effect on the stress distribution in upper premolars: 3D finite element analysis. Int. J. Odontostomat., 15(4):942-947, 2021.

\section{MATERIAL AND METHOD}

3D Modeling. The anatomical structures of a 3D upper premolar were modeled using CAD software (Rhinoceros 5.0 SR8, McNeel North America, Seattle, WA, USA). The dental tissues were individually designed containing enamel, dentin and periodontal ligament. For this, the main anatomical points were used as parameters to create the model. The first 3D model represented a healthy tooth. From the intact element, three teeth with different occlusal reductions were modeled to be rehabilitated with ceramic fragments (Fig. 1), thus totaling four groups. The distribution of the groups occurred according to the restoration thickness: Element without restoration (0) and table-top with $0.5 \mathrm{~mm}, 1 \mathrm{~mm}$ or $1.5 \mathrm{~mm}$ of maximum thickness, respectively, and denominated groups $0.5,1.0$ and 1.5 (Fig. 1).
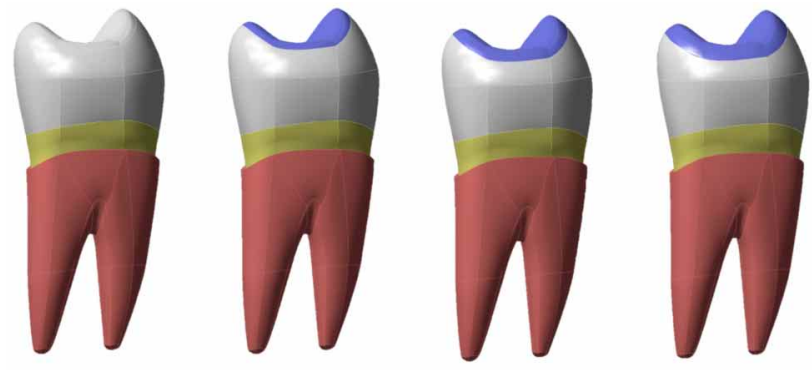

Fig. 1. Three-dimensional models used during finite element analysis. Healthy tooth model and models with restoration of $0.5 \mathrm{~mm}, 1.0 \mathrm{~mm}$ and $1.5 \mathrm{~mm}$.

Preprocessing. The solid geometries were exported to the analysis software (ANSYS 17.2, ANSYS Inc., Houston, TX, USA) in STEP format. The materials were considered isotropic, homogeneous and linear. The values of the elastic modulus and the Poisson ratio of the materials were obtained from the literature and are summarized in Table I (Singh et al., 2015; Tribst et al., 2017a; Dal Piva et al., 2017). Polyurethane structural information was used for simulation of isotropic bone tissue (Tribst et al., 2017a). Next, the mesh was generated after a convergence test at $10 \%$ significance (Dal Piva et al., 2017), presenting an average of 152,837 nodes and 84,874 elements (Fig. 2a). All contacts between the solids were considered perfectly bonded.

Loading Conditions. A physiological occlusion load was subsequently simulated with a load of $200 \mathrm{~N}$ at the edges of the crunching slopes of the buccal and palatal cusps (Fig. 2b). The system fixation was on the outer lower surface of the three-dimensional model.
Table I. Mechanical properties used in structural static analysis.

\begin{tabular}{|c|c|c|}
\hline Estructure/Material & $\begin{array}{l}\text { Elastic } \\
\text { modulus } \\
(\mathrm{GPa})\end{array}$ & $\begin{array}{l}\text { Poisson } \\
\text { ratio }\end{array}$ \\
\hline $\begin{array}{l}\text { Enamel (Tribst et al., 2017a) } \\
\text { Dentin (Singh et al., 2015) }\end{array}$ & $\begin{array}{l}84.1 \\
18.0\end{array}$ & $\begin{array}{l}0.33 \\
0.31\end{array}$ \\
\hline $\begin{array}{l}\text { Periodontal ligament (Dal Piva et } \\
\text { al., 2017) }\end{array}$ & 0.069 & 0.45 \\
\hline $\begin{array}{l}\text { Lithium dissilicate (Dal Piva et al., } \\
\text { 2017) }\end{array}$ & 95 & 0.23 \\
\hline Poliurethane (Tribst et al., 2017a) & 3.6 & 0.3 \\
\hline
\end{tabular}
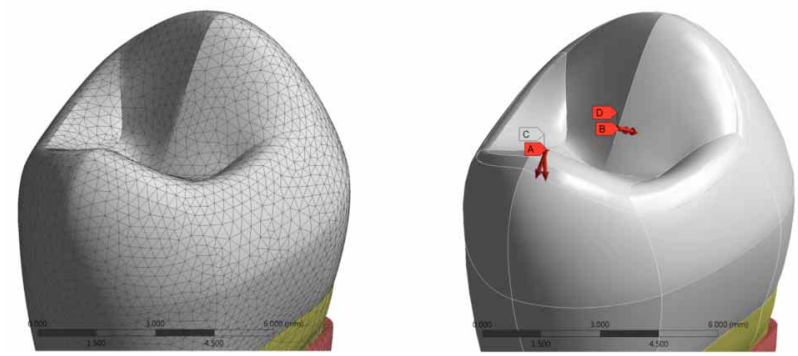

Fig. 2. Division of the finite element mesh and occlusal loading condition used during static mechanical testing.

\section{RESULTS}

The required results were at maximum principal stress (MPa) to evidence possible areas of tensile stress concentration. In this way, the more closer to the red color, the greater the stress concentration in the region. Thus, it is possible to observe that there was a minimal difference for the dental element between the restored groups under physiological load compared to the healthy tooth (Figs. 3a-d). The three restored groups presented lower tensile stress on the palatine face of the clinical crown in the dental structure than the healthy group, suggesting that occlusal restoration is not detrimental to the mechanical behavior. In the sagittal view (Figs. 3eh), it is possible to observe similar mechanical behavior between the groups in the internal region of the restoration. However, when analyzing the occlusal surface of the groups restored under the applied load (Figs. 3i-1), it is possible to notice that the thicker fragments present a lower tensile stress region, thus suggesting a better prognosis. This same mechanical behavior is observed in the adhesive face of the dental element, suggesting that thicker fragments are able to soften the tensile stress in the prepared region of the tooth (Figs. $3 \mathrm{~m}-0$ ). The mechanical behavior was more damaging in the restoration structure for all groups (Figs. 3i-1). A bar graph was plotted to quantify the numerical difference of the generated stress peaks (Fig. 4). 

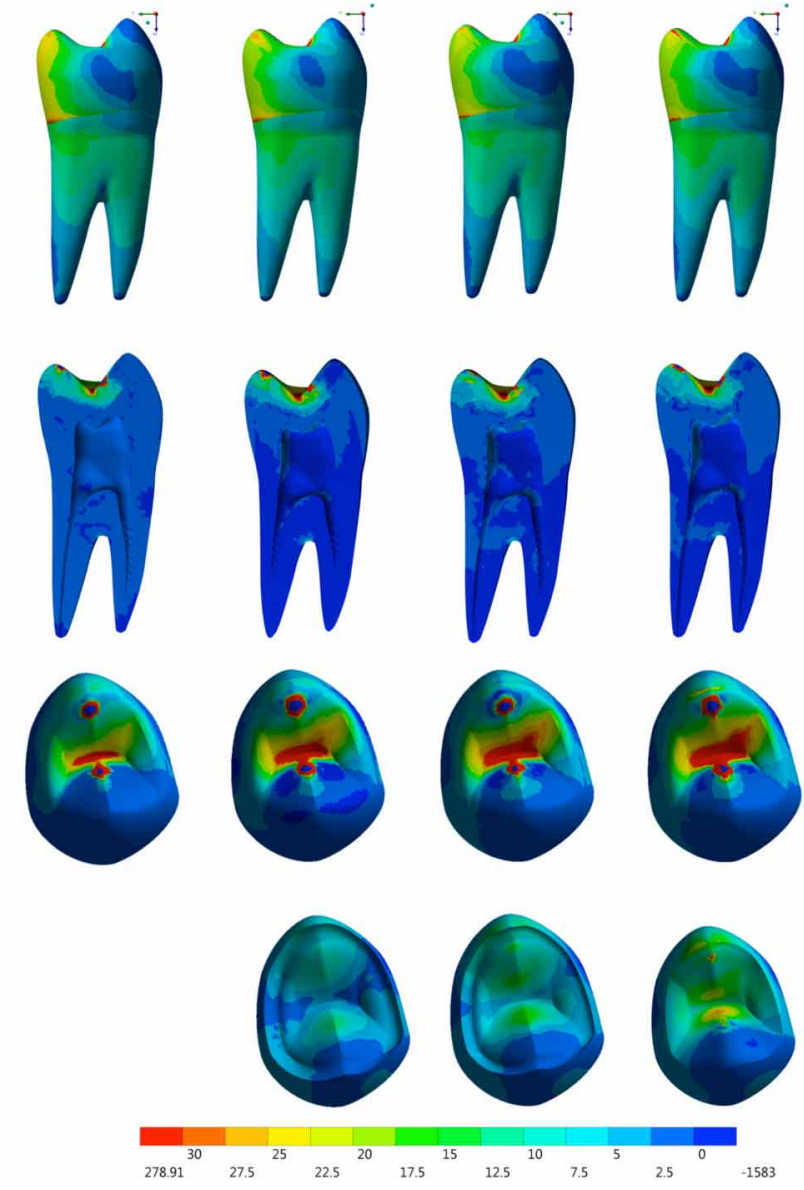

Fig. 3. Tensile stress during occlusal loading: Side, sagittal and occlusal view of stress results. Respectively, sound tooth, preparation with $1.5,1.0$ and 0.5 models.

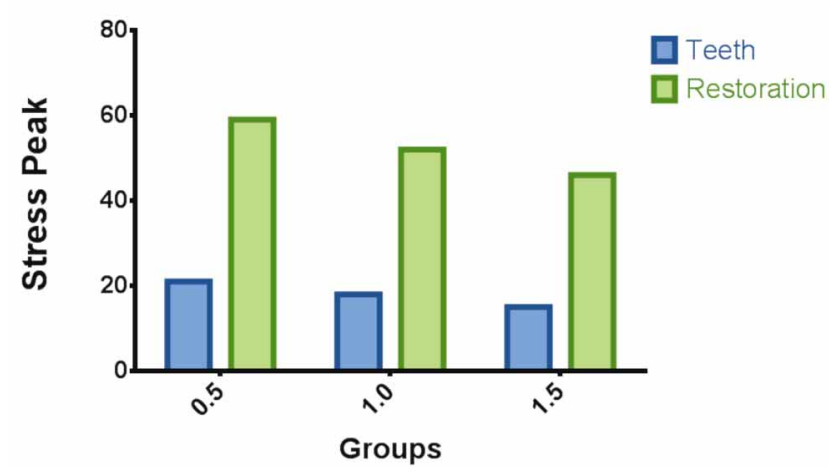

Fig. 4. Bar chart of tooth and restoration spikes for restored groups.

\section{DISCUSSION}

The present study evaluated using finite element analysis to evaluate the stress generated in upper premolars rehabilitated in the occlusal face with ceramic fragments of lithium disilicate. Table-top restorations with a thickness of $0.5 \mathrm{~mm}$ obtained a higher stress concentration in comparison to the other groups when submitted to the masticatory efforts, thereby rejecting the study hypothesis.

In relation to the dental preparation, only dental structure rounding on the occlusal surface (restricted to the enamel) was considered, simulating a common pathological wear in patients with bruxism. Preservation of the dental structure during the cavity preparations minimizes decreasing the resistance of the dental tissues (Daher et al., 2021). Thus, a conservative preparation only involving the occlusal face is feasible, since when stress values that were lower than the flexural strength of the lithium disilicate were evaluated (Campaner et al.; Dal Piva et al., 2021), for example a load of $200 \mathrm{~N}$, it is suggested that the restorations will not fracture.

The stress concentration in the tooth structure was also considered. The group with table-top of 1.5 $\mathrm{mm}$ thickness obtained the lowest stress magnitude. Although the final difference between the groups was significant based on the convergence test, we cannot assume that there will be a clinical difference, since the values found are less than $20 \mathrm{MPa}$ in all restored groups.

The rehabilitation of patients with dental wear is a matter of great relevance, as these pathological changes imply in physiological and aesthetic factors (Henriques). The decrease in OVD caused by dental wear influences the opening and closing of the mandibular arch, which may alter the direct relationship between the teeth that accompany the anterior guide, and its decrease may cause discomfort (Henriques).

Tavarez et al. (2014) proposed that aesthetic restorations made from feldspathic ceramic showing fragments and overlay type configurations, and then submitted to fracture resistance tests, resulted in the ceramic fragments obtaining better results, in addition to preventing the dental structure from becoming fragile with very extensive biomechanical preparations. Calderon et al. compared the force of maximum intercuspidation of bruxer and non-bruxer patients and observed that the presence of parafunction showed no influence on maximal force of maximum intercuspation.

Bertoncelo et al. (2014) analyzed the ceramic laminates strength by rehabilitating upper premolars. The authors observed that the restorations made in 
lithium disilicate obtained significant results, reaching $530 \mathrm{~N}$ on the compression test when compared to other ceramic systems. Thus, a physiological load of $200 \mathrm{~N}$ simulated in this study will not cause the material to fracture, corroborating with the values of the stress scale found in Figure 3.

By investigating the performance of table-tops according to the material used in confection (lithium disilicate, leucite and composite resin, all machinable) cemented in the occlusal third molars, a survival rate of $100 \%$ with $1400 \mathrm{~N}$ was observed for composite resin restorations. However, restorations of lithium disilicate under physiological load presented $100 \%$ survival, and still presented $30 \%$ survival even with more than one ton of force (Magne et al., 2010, 2012).

Although it cannot portray all the variables in the buccal environment, finite element analysis is efficient in investigating the effects of stress distribution on tabletops (Magne et al., 2012; Magne \& Cheung, 2017), identifying the initial mechanism of failure allowing new dental treatment alternatives (Tribst et al., 2017a,b; Dal Piva et al., 2017; Dal Piva et al., 2018; Tribst et al., 2018).

\section{CONCLUSIONS}

Considering the study limitations, it can be concluded that more conservative occlusal ceramic fragments present higher stress magnitude. However, restorations between 0.5 and 1.5 rehabilitating the occlusal surface of upper premolars during physiological chewing loads.

BORGES, A. L. S.; SILVA, R. S. R.; DE MATOS, J. D. M.; DAL PIVA, A M. O.; FILHO, O. D. A.; LOPES, G. R. S. \& TRIBST, J. P. M. Efecto del espesor de la restauración de cerámica de disilicato de litio de sobremesa en la distribución de tensiones en los premolares superiores: Análisis de elementos finitos 3D. Int. J. Odontostomat., 15(4):942947, 2021.

RESUMEN: El objetivo fue evaluar las tensiones generadas en los premolares superiores rehabilitados con fragmentos cerámicos (tablero) de disilicato de litio en la superficie oclusal. Se modeló un premolar superior siguiendo sus referencias anatómicas utilizando un software de diseño asistido por computadora (Rhinoceros versión 5.0 SR8, EE. UU.). Los tejidos dentales se moldearon individualmente conteniendo esmalte, dentina y ligamento periodontal. Los principales puntos anatómicos se utiliza- ron como parámetros para la creación del modelo. Los fragmentos cerámicos se modelaron variando sus espesores máximos como: $0,5 \mathrm{~mm}, 1,0 \mathrm{~mm}$ y $1,5 \mathrm{~mm}$. Las geometrías sólidas se exportaron al software de análisis (ANSYS 17.2, EE. UU.) En formato STEP. Los materiales se consideraron isotrópicos, homogéneos y lineales, y los valores del módulo elástico de los materiales y estructuras se utilizaron para realizar un análisis mecánico estructural estático. El conjunto se sometió a una carga de 200 N. La fijación del sistema se definió a partir del modelo tridimensional, y los resultados se obtuvieron en MPa según los criterios de falla de los materiales analizados (tensión de tracción). La restauración oclusal no perjudica el comportamiento mecánico. La distribución de la tensión en la región interna de la restauración es similar entre los grupos. Los fragmentos más gruesos presentaron una menor concentración de tensión de tracción, lo que sugiere un mejor pronóstico en la atenuación de las tensiones de tracción en la región dentaria. Los fragmentos cerámicos oclusales más conservadores presentaron peor pronóstico. Sin embargo, todos los espesores evaluados para tableros de mesa en disilicato de litio apoyan la rehabilitación oclusal de los premolares superiores cuando se someten a una carga de $200 \mathrm{~N}$.

PALABRAS CLAVE: cerâmica, análisis de elementos finitos, prótesis fija.

\section{REFERENCES}

Attanasio, R. An overview of bruxism and its management. Dent. Clin. North Am., 41(2):229-4, 1997.

Bertoncelo, C. A.; Moreira, M. A.; Archangelo, C. M.; Silva, C. O.; Sábio, S. \& Corrêa, G. O. In vitro evaluation of fatigue resistance and adhesion laminated ceramics veneers in premolars with total coverage of the buccal cusp. Uningá Rev., 19(1):10-3, 2014.

Calderon, P. S.; Kogawa, E. M.; Lauris, J. R. \& Conti, P. C. The influence of gender and bruxismo on the human maximum bite force. J. Appl. Oral Sci., 14(6):448-53, 2006.

Campaner, L. M.; Silveira, M. P. M.; De Andrade, G. S.; Borges, A. L. S.; Bottino, M. A.; Dal Piva, A. M. O.; Lo Giudice, R.; Ausiello, P. \& Tribst, J. P. M. Influence of polymeric restorative materials on the stress distribution in posterior fixed partial dentures: $3 \mathrm{D}$ finite element analysis. Polymers (Basel), 13(5):758, 2021

Costa, V. L. S.; Tribst, J. P. M. \& Borges, A. L. S. Influence of the occlusal contacts in formation of Abfraction Lesions in the upper premolar. Braz. Dent. Sci., 20(1):115-23, 2017.

Culp, L. \& McLaren, E. A. Lithium disilicate: the restorative material of multiple options. Compendium, 31(9):716-25, 2010.

D’Arcangelo, C.; Vadini, M.; D’Amario, M.; Chiavaroli, Z. \& De Angelis, F. Protocol for a new concept of no-prep ultrathin ceramic veneers. J. Esthet. Restor. Dent., 30(3):173-9, 2018.

Daher, R.; Ardu, S.; Di Bella, E.; Rocca, G. T.; Feilzer, A. J. \& Krejci, I. Fracture strength of non-invasively reinforced MOD cavities on endodontically treated teeth. Odontology, 109(2):368-75, 2021.

Dal Piva, A. M. O.; Tribst, J. P. M. \& Bottino, M. A. Evaluation of shear bond strength and shear stress on zirconia reinforced lithium silicate and high translucency zirconia. J. Oral Res., 7(1):30-6, 2018. 
Dal Piva, A. M. O.; Tribst, J. P. M.; Jalkh, E. B. B.; Anami, L. C. Bonfante, E. A. \& Bottino, M. A. Minimal tooth preparation for posterior monolithic ceramic crowns: Effect on the mechanical behavior, reliability and translucency. Dent. Mater., 37(3):e14050, 2021.

Dal Piva, A. M. O.; Tribst, J. P. M.; Souza, R. O. A. E. \& Borges, A. L. S. Influence of Alveolar Bone Loss and Cement Layer Thickness on the Biomechanical Behavior of Endodontically Treated Maxillary Incisors: A 3-dimensional Finite Element Analysis. J. Endod., 43(5):791-5, 2017.

Dawson, P. E. Optimum TMJ condyle position in clinic pratice. J. Periodontics Restorative Dent., 5(3):10-31, 1985.

Henriques, S. E. F. Reabilitação Oral: Filosofia, Planejamento e Oclusão. São Paulo, Santos Editora, 2003.

Kelly, J. R. \& Benetti, P. Ceramic materials in dentistry: historical evolution and current practice. Aust. Dent. J., 56(1):84-96, 2011.

Kwon, S. J.; Lawson, N. C.; McLaren, E. E.; Nejat, A. H. \& Burgess, J. O. Comparison of the mechanical properties of translucent zirconia and lithium disilicate. J. Prosthet. Dent., 120(1):132-7, 2018.

Magne, P. \& Cheung, R. Numeric simulation of occlusal interferences in molars restored with ultrathin occlusal veneers. J. Prosthet. Dent., 117(1):132-137, 2017.

Magne, P. \& Knezevic, A. Influence of overlay restorative materials and load cusps on the fatigue resistance of endodontically treated molars. Quintessence Int., 40(1):729-37, 2009.

Magne, P.; Schlichting, L. H.; Maia, H. P. \& Baratieri, L. N. In vitro Fatigue resistance of CAD/CAM composite resin and ceramic posterior occlusal veneers. J. Dent., 104(3):149-57, 2010.

Magne, P.; Stanley, K. \& Schlichting, L. H. Modeling of ultrathin occlusal veneers. Dent. Mater., 28(7):777-782, 2012.

Matos, J. D. M.; Nakano, L. J. N.; Bottino, M. A.; Jesus, R. H. \& Maciel, L. C. Current considerations for dental deramics and their respective union systems. Rev. Bras. Odontol., 77(1):e1768, 2020.

Miyashiro, M.; Suedam, V.; Moretti Neto, R. T.; Ferreira, P. M. \& Rubo, J. H. Validation of an experimental polyurethane model for biomechanical studies on implant supported prosthesistension tests. J. Appl. Oral Sci., 19(3):244-8, 2011.

Okeson, J. P. Fundamentos da Oclusão e Desordens Temporomandibulares. 4. ed. São Paulo, Artes Médicas, 2000.

Singh, S. V., Bhat, M.; Gupta, S.; Sharma, D.; Satija, H. \& Sharma, S. Stress distribution of endodontically treated teeth with titanium alloy post and carbon fiber post with different alveolar bone height: A three-dimensional finite element analysis. Eur. J. Dent., 9(3):428-32, 2015.

Tavarez, R. R. J.; Firoozmand, L. M.; Silva, M. B.; Malheiros, A. S. \& Bandéca, M. C. Overlays or Ceramic Fragments for Tooth Restoration: An Analysis of Fracture Resistance. J. Contemp. Dent. Pract., 15(1):56-60, 2014.

Tribst, J. P. M.; Alves, L. M. M.; Dal Piva, A. M. O.; Melo, R. M.; Borges, A. L. S.; Paes-Junior, T. J. A. \& Bottino, M. A. Reinforced glass-ceramics: Parametric inspection of three-dimensional wear and volumetric loss after chewing simulation. Braz. Dent. J., 30(5):505-10, 2019.

Tribst, J. P. M.; Dal Piva, A. M. O. \& Borges, A. L. S. Biomechanical behavior of indirect composite materials: a 3D-FEA study. Braz. Dent. Sci., 20(1):52-57, 2017a.

Tribst, J. P. M.; Dal Piva, A. M. O.; Penteado, M. M.; Borges, A. L. S. \& Bottino, M. A. Influence of ceramic material, thickness of restoration and cement layer on stress distribution of occlusal veneers. Braz. Oral Res., 32(0):e118, 2018.

Tribst, J. P. M.; De Morais, D. C.; Alonso, A. A.; Dal Piva, A. M. O. \& Borges, A. L. S. Comparative three-dimensional finite element analysis of implant-supported fixed complete arch mandibular prostheses in two materials. J. Indian Prosthodont. Soc., 17(1):255-60, 2017b.
Tribst, J. P. M.; Lo Giudice, R.; Dos Santos, A. F. C.; Borges, A. L. S.; Silva-Concílio, L. R.; Amaral, M. \& Lo Giudice, G. Lithium disilicate ceramic endocrown biomechanical response according to different pulp chamber extension angles and filling materials. Materials (Basel), 14(5):1307, 2021.

Wigdorowicz-Makowerowa, N.; Grodzki, C.; Panek, H.; Máslanka, T.; Plonka, K. \& Palacha, A. Epidemiologic studies on prevalence and etiology functional disturbances of the masticatory system. J. Prosthet. Dent., 41(1):76-82, 1979.

Corresponding author:

Jefferson David Melo de Matos

D.D.S.; M.D.; Ph.D. Student.

Post Graduate Student - Ph.D Program

Department of Dental Materials and Prosthodontics

São Paulo State University (Unesp)

Institute of Science and Technology

São José dos Campos - SP.

Avenida Engenheiro Francisco José Longo, 777/778

Jardim São Dimas

São José dos Campos - SP

CEP: 12245000

BRAZIL

E-mail: matosjefferson19@gmail.com

ORCID: https://orcid.org/0000-0003-4507-0785 